\title{
SOME CHARACTERISTICS OF THE EXTERNAL EAR OF AMERICAN WHITES, AMERICAN INDIANS, AMERICAN NEGROES, ALASKAN ESQUIMOS, AND FILIPINOS
}

\author{
ROBERT BENNETT BEAN
}

The Anatomical Laboratory of the Tulane University of Lowisiana EIGHTEEN FIGURES (THREE PLATES)

The study of the external ear of man was begun by me in 1905, although I had been making casual observations even before this. While in the Philippines from 1907 to 1910 I segregated many forms of ears, grouping them under three main heads which I called Primitive, Australoid and Iberian for various reasons then set forth (1). Other considerations prevailed and I changed the names from Primitive to Hypo-onto-morph, from Australoid to Meso-onto-morph, and from Iberian to Hyper-ontomorph (2).

The present study is a continuation of those made previously and is more detailed and specific than former studies. It corroborates them in general and in particular, and adds racial distinctions to type differences.

\section{MATERIALS}

Morgue subjects

86 ears of New Orleans whites 200 ears of New Orleans negroes 94 ears of Manila Filipinos

\section{Living subjects}

103 ears of New Orleans students (white)

94 ears of New Orleans negroes

182 ears of American 'old whites' (three or more generations in America)

222 ears of Washington, D. C., negroes

73 ears of American Indians

171 ears of Alaskan Eskimos

68 ears of fetuses, newborn, and young infants (dead) 
This paper is divided into two parts: "Ears of the morgue subjects," and "Ears of the living subjects."

\section{EARS OF THE MORGUE SUBJECTS}

The ears of the morgue subjects were measured in 1914 after having been preserved in formalin for variable periods of time from a few weeks to several years.

Each ear was measured as prescribed by Schwalbe, Ranke, Martin and others $(13,15,16)$. Seven measurements of each ear were made, the total length, total breadth, cartilage length, ear base, Schwalbe's true ear length (15), the concha length and concha breadth. The concha breadth and length are measurements devised by me to determine the concha index. The concha length is measured from the point where the inferior crus of the concha emerges from the ascending helix, to the inferior border of the intertragic incisure. The concha breadth is measured from the supra-tragic incisure to the point at the greatest distance from this on the inside of the concha opposite.

\section{Helix. Measurements and indices}

The average total length and breadth of the ear in millimeters follows:

TABLE 1

Total length of the ear, average in millimeters

\begin{tabular}{r|l|c|c|c}
\hline No. OF EARS & \multicolumn{1}{|c|}{ RACE; SEX } & RIGHT EAR & LEFT EAR & BOTH EARs \\
\cline { 2 - 3 } $67 \ldots \ldots$ & White men & 64.95 & 63.20 & 64.18 \\
$120 \ldots \ldots$ & Negro men & 58.81 & 58.33 & 58.58 \\
$31 \ldots \ldots$ & Negro women & 57.67 & 59.31 & 58.32 \\
$80 \ldots \ldots$ & Filipino men & 59.69 & 58.43 & 58.80 \\
$14 \ldots \ldots$ & Filipino women & 57.86 & 57.00 & 57.43 \\
$19 \ldots \ldots$ & White men & 65.20 & & \\
$41 \ldots \ldots$ & Negro men & 59.30 & & \\
$8 \ldots \ldots$ & Negro women & 57.90 & & \\
\hline
\end{tabular}


TABLE 2

Total breadth, average, in millimeters

\begin{tabular}{r|l|c|c|c}
\hline No. OF EARS & \multicolumn{1}{|c|}{ RACE; SEx } & RIGHT EAR & LEFT EAR & BOTH EARS \\
\hline $67 \ldots \ldots$ & White men & 37.65 & 36.85 & 37.19 \\
$120 \ldots \ldots$ & Negro men & 37.78 & 37.05 & 37.43 \\
$31 \ldots \ldots$ & Negro women & 35.61 & 35.69 & 35.63 \\
$80 \ldots \ldots$ & Filipino men & 33.71 & 33.43 & 33.57 \\
$14 \ldots \ldots$ & Filipino women & 33.30 & 32.57 & 32.94 \\
$19 \ldots \ldots$ & White men & 38.60 & & \\
$41 \ldots \ldots$ & Negro men & 37.40 & & \\
$8 \ldots \ldots$ & Negro women & 37.10 & & \\
\hline
\end{tabular}

Physiognomic index of Topinard (16) is the breadth divided by the length:

TABLE 3

Physiognomic index

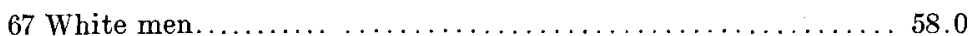

120 Negro men... ................................. 64.0

27 Negro men.................................... 60.8

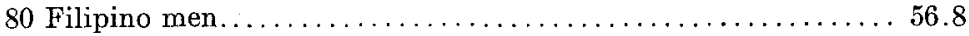

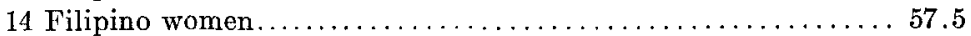

According to Martin (13) the lowest index of any race so far measured is that of the Aino, 52.8, and the highest is that of the Mawamba pigmies; 66.2. Europeans, as a rule, have a low index, below 60.0, although Alsatians (Schwalbe) have an index of 60.5 (15) and the negroes as a rule have a high index, above 60.0 , although the Hottentots have an index of 58.8 [Karutz (12) ]. The index of the new born is high, 73.7 for males and 73.1 for females, and it sinks to 58.7 at 70 years of age [Daffner (6) $]$.

Modulus: The ear modulus is obtained by adding the total length of the ear to the total breadth and dividing by two. This gives the ear size in a factor of convenient form. The average module of 67 ears of white men is 50.69 , of 120 negro men is 48.0 and of 27 negro women is 46.86 . The module for 80 Filipino men is 46.19 , for 14 Flipino women 45.19 . 
Résumé of the total ear dimensions: The ears of the white men are longer than those of the negro men and of about the same breadth. The ears of the negro women are about the same length as those of the negro men but not so broad. The ears of the white men are long and narrow, the ears of the negro men are relatively short and broad, the ears of the negro women are relatively short and narrow and the ears of the Filipinos are short and narrow, relatively narrower than any of the others. The ears of the white men are large, the ears of the negro men and women are small, those of the negro women smaller than those of the negro men, and the ears of the Filipinos are smaller than any of the others, the ears of the Filipino women are the smallest of all.

Morphologic index: Schwalbe (15) introduced an index of the ear which is obtained by dividing the ear base by the true ear length. Taking a series of mammals up to man this index increases from 27.6 in the antelope through the kangaroo 33.0 , the lemur 76:0, the monkey 84.0-93.0, the chimpanzee 105.0, the orang 122.0 , the gorilla 125.0 , the negro women of New Orleans 172.67 , the negro men of New Orleans 177.9 , to the white men of New Orleans 180.2. The Filipino men have an index of 188.9 and the Filipino women 193.96. The index of the Bavarians is 122.0, Great Russians 139.8, Kalmucks 140.6, and Ainos 171.5 (13). The morphologic index is vitiated by the difficulty of finding Darwin's tubercle in a large number of ears. Martin (13) considers the index of doubtful value. The variability is very great, 83.7 to 195.5 in Alsatian men, 97.3 to 189.5 in Alsatian women, 110.0 to 223.0 among the Ainos, and 133.0 to 255.0 among the negro men of New Orleans.

\section{Concha. Measurements and indices}

Length: The length of the concha is $24.79 \mathrm{~mm}$. in 56 ears of the white men, $24.25 \mathrm{~mm}$. in 115 ears of the negro men, 24.04 $\mathrm{mm}$. in 29 ears of the negro women, 24.62 in 80 ears of the Filipino men and $23.57 \mathrm{~mm}$. in 14 ears of the Filipino women.

Breadth: The breadth of the concha is $19.14 \mathrm{~mm}$. in 56 ears of the white men, $20.01 \mathrm{~mm}$. in 115 ears of the negro men, 19.24 
$\mathrm{mm}$. in 29 ears of the negro women, 17.0 in 80 ears of the Filipino men and 16.93 in 14 ears of the Filipino women.

Index: The index of the concha, as instituted here by me for the first time, is obtained by dividing the length into 100 times the breadth. The index represents the breadth of the concha in terms of the length, the latter always 100 . If the index is high, the concha is relatively broad, if the index is low the concha is relatively narrow. The index is 77.21 for the ears of the white men, 82.52 for the ears of the negro men, 80.03 for the ears of the negro women, 69.0 for the ears of the Filipino men and 72.0 for the ears of the Filipino women.

The concha index is more variable among the negroes than among the whites and it is more variable among the negroes than either the physiognomic or morphologic index. The great variations of the concha index need not vitiate its importance, but may add to its significance by indicating the degrees of mixture of negro and white.

The ears of the negro men with a concha index of 81 and over are more like the ears of the negro, because the average total ear length of the ears in this group is $5.6 \mathrm{~mm}$., and the average age total breadth is $3.7 \mathrm{~mm}$., with a physiognomic index of 66.1 ; whereas the average total ear length of the ears of the negro men with a concha index of 80 and less is $6.1 \mathrm{~mm}$., the average total breadth is $3.8 \mathrm{~mm}$., and the physiognomic index is 62.3 , and the ears are therefore like the ears of the white. The concha index is thus proven useful as a racial differentiator of a mixed group.

There is a close correlation between the concha index, the morphologic index, and the physiognomic index.

\section{Descriptive characters (plates 1 to 3 )}

True negro ear: In addition to the measurable characters of the negro ear there are descriptive characters which are as distinctive as the measurable ones and they may enable the observer to obtain a clearer picture of the true negro ear and its parts (12). The ear is small, almost flat, close to the head, and the helix is broad as if much folded over. The upper part of 
the helix is almost horizontal and passes almost directly backward from the upper end of the ear base to join the vertical dorsal portion of the helix at a right or acute angle in a rounded point at the upper outer extremity of the ear. The superior and dorsal borders of the helix are separated by a depression above Darwin's tubercle where the helix is thin or absent. The dorsal border passes downward and turns forward at an obtuse angle to form the inferior border of the ear which enters the cheek almost at right angles, with no lobule, or a very small one which is nearly flat (figs. 1-12).

The satyr tubercle is well marked and Darwin's tubercle is small or absent. The skin lines formed by the infolding of the helix are less distinct on the true negro ear than on the white, and they usually converge on the true negro ear over Darwin's tubercle. The concha, like the ear as a whole, is wide and short. The true negro ear, is not seen in great numbers among American negroes. It occurred 245 times among 1478 New Orleans negroes (16.6 per cent), men, women and children, chiefly of the laboring classes.

Involuted ear: There is another form of ear that is found chiefly among the negroes, but it is also found not rarely among other peoples, even among the whites, and I have called this 'the involuted ear' because it seems to represent an advanced stage in regressive evolution. It is the ear with a broad helix that is much rolled in and frequently has a gnarled or crumpled appearance, as if the ear had been burned around the border and had contracted irregularly in healing, leaving a thick, distorted helix. This ear type in its crumpled condition was at first thought to be due to accidental causes, but the presence of the skin lines of the ear tip in regular order proved the ear to be a true type. This ear form has been described by Fischer as the Hottentot ear (7). It was found 601 times in 1478 New Orleans negroes (40.7 per cent) and 52 times among 857 New Orleans whites (6.1 per cent). The individual characters of the ears of both whites and negroes will next be presented in detail.

Darwin's tubercle: There are three prominent parts of the inner or ventral border of the helix called the Satyr tubercle, 
Darwin's tubercle and one below this that I will name here for the first time the 'inferior tubercle' of the helix. This tubercle is illustrated by Münch (14) in his study of the development of the ear cartilage. Between these there are two depressions, one at the upper outer corner of the ear between the satyr tubercle and Darwin's tubercle, and one on the dorsal border of the helix between Darwin's tubercle and the inferior tubercle. The three tubercles and the two depressions are made by the unequal turning in of the helix of the ear in the fetus.

Darwin's tubercle is small or absent in the negro, and large in the Filipino, although it is more often absent among them than among the others. It is also small in the white although there are many ears with large tubercles among the whites.

\section{Skin lines on the helix (plates 1 and 2 )}

The position of the skin lines on the helix caused by the infolding of the tip were first seen in 1914 when I was making the drawings of the ears in figures 1 to 12 . These lines have never before been described although they may be seen on practically all adult ears. They converge from the outer to the inner border of the helix beneath the prominence of Darwin's tubercle, or adjacent to it, although they may be seen rarely on the dorsal side of the helix. By their usual position they seem to indicate that the skin has been pulled forward under Darwin's tubercle or has been held there while the adjacent parts of the helix develop more rapidly, leaving lines that represent foldings of the skin.

The lines are more often absent or obscure on the ears of the negroes and Filipinos than on the ears of the whites. The skin lines are more scattered on the ears of the whites and more often occur about Darwin's tubercle on the ears of the others. The lines are also higher up on the helix of the white ears than on the helix of the others, and often appear over the satyr tubercle of the white ear. This may be due to the more regular form of the white ear and to the fact that the satyr tubercle is larger in the negro than in the white, and is turned over from above more in the former than in the latter. This rolling over of the satyr 
tubercle in the negro ear may prevent the lines from forming above Darwin's tubercle as the latter undegoes retrograde metamorphosis.

The satyr tubercle is large in the negro ear, small in the white ear, and intermediate in the Filipino ear.

The helix of the negro ear is broad, the helix of the Filipino ear is narrow, and the helix of the white ear is intermediate. The broadness of the helix in the negro ear is especially well seen in the upper border in the region of the satyr tubercle, and this border of the ear is horizontal and at right angles to the ear base. There is evidence of greater inrolling of the negro ear in this part, which accounts for the shape of the negro ear, quadrangular, or pentagonoid, and also for its small size, and its greater breadth and less height or length, its short, broad concha, its small base and long true ear diameter.

The lobule is absent or small more frequently from the ears of the negroes and Filipinos than from the ears of the whites, and it is absent or small more frequently from the ears of the women than of the men. Keith (13) gives an increasing size of the lobule in the following order: Orang, chimpanzee, gorilla, negro, British. According to Martin the lobule is absent oftenest in the negroes, less in the Asiatics and least in the Europeans. It is also absent more frequently among the defectives than among normal individual (Bertillon).

The helix and other parts of the ear may be examined for their relative projection from the head, and as this determines in part the Hypo-, Meso and Hyper types of the ear it will lead up naturally to a consideration of these three types.

The negro men have projecting helices, the white men have projecting anthelices, the Filipino men resemble both the white and negro men, and the negro and Filipino women resemble the white men more than they do the negro men.

The lobule and the inferior border of the helix: This part of the ear is turned from the head in the negro men, and in toward the head in the white men, and the negro women resemble the white men in this respect. 
The posterior auricular sulcus: The sulcus turns into the concha in the negro men, out over the helix or lobule in the white men, and in the Filipino men it does both. The negro and Filipino women are like the white men in this respect.

Tragus and antitragus: The negro men's ears have depressed or intermediate antitragus and tragus, and the white men's ears have prominent ones, in which the ears of the Filipino men and women and the negro women resemble the white men.

Asymmetry: (8) The ears of the negro men are asymmetrical in 33.3 per cent, and asymmetrical in 66.7 per cent; the ears of the negro women are asymmetrical in 30.0 per cent, and symmetrical in 70 per cent, and the ears of the white men are asymmetrical in 25 per cent and symmetrical in 75 per cent. This does not include slight differences, but only such as an oval ear on one side and a pentagonoid ear on the other, or the absence of lobule on one side and its presence on the other, etc. The ears of the two sides are almost invariably asymmetrical in a slightly different arrangement of the skin lines, different curves of the helix, depths of the concha, etc.

Résumé: The details of the ears of the negro and white are different as follows: The negro ears are glabrous, the white ears are hirsute; the satyr tubercle is large in the negro ear, small in the white; Darwin's tubercle is more difficult to find in the negro ear than in the white; the skin lines converge about Darwin's tubercle in the negro ear, and between Darwin's tubercle and the satyr tubercle in the white; the helix is broad in the negro ear, narrow in the white; the anthelix is more prominent in the white ear than in the negro; the posterior auricular sulcus is deeper in the negro ear than in the white, and in the negro ear the sulcus dips into the concha, whereas in the white it turns out over the helix or lobule. Also in the white ear the helix and lobule are turned towards the head and are not prominent, and the tragus and antitragus are turned away from the head and are prominent, whereas in the negro the reverse is true. The white ear is also more symmetrical than the negro, and the negro ear is involuted, whereas the white ear is not. All of these characters are mixed 
in the Filipino ears, evidence of Negrito and European stock as their basis. The true negro ear and the involuted ear are characteristic negro ears, and they both represent great regression in evolution. This regression is represented by the involution of the helix, which is turned in and is broader in the negro than in the white. The involution is present on the few fetal negro ears I have examined as early as the third or fourth month at which time other negro characteristics are present. For this reason it seems to be rather a condition of regression in evolution than of retrograde metamorphosis in development. The small size of the negro ear, the great breadth and irregularity of the helix and the absence of hair all point to the negro ear as more advanced in regressive evolution than the white, and further removed from the apes.

\section{Three fundamental ear types (plates 1 to 3 )}

It should be plain from the foregoing that the ears of the Filipinos, negroes and whites are different, and the form of the true negro ear, and the involuted ear should be clear, but there are other forms than these among the ears examined, forms that are characteristic of three types of white ears, but that may and do appear among all peoples of the world. The three types I have called the Hypo-, Meso-, and Hyper- types, and each of the three types may be subdivided into onto-morph and -phylomorph forms, the phylo, the primordial form and the onto, the derived form. At birth the white child is a Hypo-phylomorph, and as the child develops its passes consecutively through the stages of the Hypo-onto-morph, Meso-phylo-morph, Mesoonto- morph, Hyper-phylo-morph and Hyper-onto-morph, unless development stops at or between one or the other of the types. This is a process of differentiation and not of growth, because the Hyper-onto-morph, which is apparently the most highly differentiated type, is the smallest when the adult state is reached. The Hyper-onto-morph, the Meso-onto-morph, the Hyper-phylo-morph and very rarely the Hypo-onto-morph are European, or white, types in the adult; whereas the Hypophylo-morph, the Meso-phylo-morph, and rarely the Hyper- 
phylo-morph are types of the negroes, Filipinos, and other primitive peoples.

It may be clearer to omit these distinctions at this time and to confine the grouping of the three types, Hypo; Meso, and Hyper, which are readily distinguishable. When this study was begun and the observations made, first the ear type was written down on the card for the ear to be described, then each part of the ear was described in detail, the skin lines, hair, Satyr tubercle, Darwin's tubercle, helix, anthelix, posterior sulcus, tragus, antitragus, lobule, etc. From the data thus obtained the following facts have been collected:

Hypo (plate 3): The helix is prominent, the lobule turns away from the head, the anthelix is intermediate, and the tragus and antitragus are depressed in the Hypo ear, therefore the ear is bowl-shaped or trumpet-like. The flaring ear of the other types must not be mistaken for the Hypo ear, because the flaring ear is due to a wide dorsal wall in the concha, which makes the ear stand out, whereas the Hypo type of ear is due to a greater rolling over of the helix all around to the lobule which forms a shelf. This is not the extreme and disordered rolling over of the helix as in the true negro and involuted ears, but the helix presents the form of a round roll like a thickened and turned in edge of a bowl or trumpet.

Hyper (plate 3): The helix and lobule turn towards the head, the anthelix is prominent and the tragus and antitragus project from their surroundings in the Hyper ear. The helix is thin all around, and has turned in very little except at the upper part, and even this is not rolled in to a great extent. None of the tubercles of this type of ear are large, due to the slight development of the helix. It looks as if the helix had stopped developing early and the other parts of the ear had continued to develop which results in a contracted helix, and as the helix had not rolled in enough to contract forward, it turns backward more or less behind the ear. The edge of the helix has a semispiral or italic $f$ shape, or the shape of the old English letter $s$, when the ear is viewed from behind. This type of ear is the most distinctive of the three and the type of individual called the Hyper-onto- 
morph is the most distinctive of all individuals. It is that type which is small, thin, wiry, and nervous, with long narrow. head, long narrow nose, long narrow face, with pointed chinthe 'hatchet face,' as the Australians call the Englishmen in derision. This type has been found by me to have a very short intestine, sometimes only twelve feet in length, and it has also been found to have a low pylorus and duodenum, a low hepatic and splenic flexure of the colon, and a low transverse colon. The suggestion has therefore been advanced by Goldthwait, Brown (4) and others that the Hyper-onto-morph is immature, an under-developed individual morphologically. Also that it is the carnivorous type of Treves and others. There can be no doubt that the type is the end product of a hyperactive thyroid gland. The individuals are prococious in the development of the teeth, nose, face, head, and general body form (3). Their development may be so rapid that such structures as the ears, stomach, small and large intestine fail to finish their growth and transformation. Other evidences of thyroid activity are that the individuals are nervous, high-strung, and very active mentally, and there is a low grade of exophthalmos, the eyes are wide open and often present the wild look of a surprised animal, a condition that has been noted especially among the IndoEuropean women, and is considered to be a mark of beauty. They are susceptible to diseases of the alimentary canal, nervous system and lungs (epitheliopaths), as well as exophthalmic goiter. They have small bones and there is evidence of calcium insufficiency due to the thyroid secretion.

The Hyper type I have called an epitheliopath, and the Meso a mesotheliopath, because of the susceptibility of the epithelial tissues to disease in the Hyper type and the susceptibility of the mesothelial tissues to disease in the Meso type. Goldthwait of Boston has carried my work further and has demonstrated that a large majority of the inmates of insane asylums are of the Hyper type and that this type is susceptible to joint affections. Percy Brown of Boston has demonstrated associated alimentary diseases with the Hyper type (4), and Bryant of Boston has utilized the Hyper and Meso type in a successful rational 
diet, feeding the Hyper on concentrated nutrition, meat, eggs, and milk, because the intestine is short, and feeding the Meso on coarse bulky foods because the intestine is long. I may add the results of measuring the intestine in the dissecting room during the past two years (2).

Fourteen subjects of the Hyper type have an average length of 17.2 feet for the small intestine, the shortest 10 . feet and the longest 27; eleven subjects of the Meso type had an average length of 23.3 feet for the small intestine, the shortest 16.3 feet and the longest 29.5; and 27 subjects of the Meso-Hyper type have an average length of 20.8 feet for the small intestine, the shortest 16 feet, the longest 29 feet. Only one subject of the Hypo type had the small intestine measured, and the length in that one was 16.9 feet. The lengths are only approximate because of difficulties in measuring, but the condition is evident and the correlation positive.

The Hyper type of ear and the Hyper type of person may be looked upon as the result of rapid transformation with slow growth, and the Hypo type of ear and the Hypo type of person may be looked upon as the result of slow transformation with rapid growth. We are reminded of the work of Gudernatsch (10) and his feeding experiments with tadpoles, in which he obtained the Hyper type of tadpole by feeding tyhroid gland, and the Hypo type by feeding thymus gland. Reasoning from this we may suppose that the Hypo type of man is due to excessive secretion of the thymus gland during development, and that the Hyper type of man is due to excessive secretion of the thyroid gland during development.

In connection with conditions of Hypo-morphism and Hypermorphism, I would like to present observations made from time to time on two children, Mary, aged 7; Helen, aged 2. Mary was the first child, Helen the third. During the first pregnancy there was evidence of increased activity of the thyroid gland in the mother; during the third there was evidence of less activity of the thyroid gland in the mother. Mary was prematurely born about 1 month. Helen was delayed several weeks. Mary has been premature in everything except size, has metamorphosed 
rapidly but grown slowly. Helen has been delayed in everything except size, has metamorphosed slowly but has grown rapidly. Mary had a Hyper ear at birth, Helen had a Hypo ear at birth. Mary's nose was long at birth and rapidly approached the Hyper form, Helen's was short at birth and has retained the Hyper form. Mary's head elongated rapidly. Helen's elongated slowly. Mary crawled, climbed, stood alone, walked and talked earlier than Helen. Mary's teeth are small and apparently immature, Helen's are large and perfect. Mary is Hyper with rapid metamorphosis and slow growth, and Helen is Hypo with slow metamorphosis and rapid growth. I shall watch with interest their future development.

The Meso ear has a prominent or intermediate helix, lobule and anthelix, and a depressed or intermediate tragus and antitragus. The ear is nearly flat, the bowl is shallow, and the helix is not so much rolled in as in the Hypo ear. The Meso ear type is somewhat intermediate between the Hypo and Hyper types and it may be considered as the fundamental or generalized type of ear from which the Hypo and Hyper type have evolved in different directions.

The Meso ear is usually large and thick and heavy. The helix and anthelix being equally prominent a double roll is formed near the dorsal margin of the ear. The lobule and lower helix turn out from the head in the form of a shelf, and not to the same extent as in the Hypo ear, and the shelf, instead of being horizontal as in the Hypo ear, has a gentle slope forward or may be precipitous. At times the ear is almost flat, and quadrangular in shape.

Hyper-phylo-morph: An ear that is more or less intermediate between the Hyper and Meso types occurs frequently. The Hyper characteristics predominate although in each ear some Meso characteristics may be seen. This is a male ear type because very few appear among the women.

It may be well to determine the relation of the form of nose, head and face to the type of ear.

Nasal index and ear type: The noses of the persons with Hypo ears are relatively broader than those with Hyper ears 
and the noses of the negroes are broader than those of the whites. The nose of those negroes with involuted ears is about the same as those of the Hyper-phylo-morph type.

Cephalic index and ear type: There is not the same regularity of difference here as in the nasal index and ear type although the negro woman shows the same regularity. In the latter the head is relatively broad in the Hypo and relatively narrow in the Hyper. The heads of the negroes with involuted ears are relatively long and narrow, and as this is characteristic of the negro head in general, we may attribute this to the fact that involuted ears are characteristic of the negro also.

Face index and ear type: The face index is better than the cephalic index as a differentiator, but it not so good as the nasal index. The face of the Hyper is relatively longer and narrower than that of the Hypo or Meso. The face of the white man is relatively longer and narrower than that of the negro man or woman.

\section{EARS OF THE LIVING SUBJECTS}

The data for the ears of the Eskimos, American Indians, negroes of Washington, D. C., and 'old whites' (3rd generation or over, in America) came to me through Dr. Hrdlicka, and a part at least has not before been published. The measurements were made of the left ear only, of the Eskimo, by Dr. Riley D. Moore, and of the others by Dr. Hrdlicka. Only the total length and total breadth were taken.

The Eskimo has the longest ears, the Indian is next, the 'old white' third, the New Orleans students fourth and the negro has the shortest ear. Comparing these with the morgue subjects, the latter have slightly shorter ears (white and negro) and the Filipinos have the shortest ears of all. The difference in length between the 'old whites' and the New Orleans students may be due to difference in age as the students are younger and ear length increases with age.

The Eskimo has the broadest ear, the Indian next, the 'old white' next, the student next and the negro has the narrowest ear. Compared with the morgue subjects the living have nar- 
rower ears (white and negro) and the Filipinos have the narrowest ears of all.

The Indians have the largest ears, the- Eskimos next, the 'old whites' next, the students next, and the negroes the smallest. Compared with the morgue subjects, black and white, the ears of the living are larger, and the ears of the Filipinos are the smallest of all. The small size of the Filipino ears is probably due to the small size of the Filipino people and to the negro (Negrito) mixture. The small size of the negro ear is a racial trait, and is not due to the size of the American negro, who is not a pigmy but almost as large as the American white or American Indian, and larger than the Eskimo.

The negroes have the highest physiognomic index, the students next, the 'old whites' next, the Eskimos next, and the Indians have the lowest index. Compared with the morgue subjects, black and white, the index of the living is less. The Filipino's index is greater than any of the living except the students and negroes, although it is less than the morgue white. By relative physiognomic index the Filipino would be classed with the Eskimo and Indian, and the white in each case is between these and the negro. The Filipino has a large portion of Negrito, which is evident because of the presence of negro and involuted ears in large numbers among them, but the physiognomic index does not show this.

The Filipino, Eskimo and Indian are related to the Mongolian in the physiognomic index of the ear and this relationship is apparently so strong that it is shown in the ear form, in spite of the large share of negro (Negrito) mixture in the Filipino.

The ear length increases with age to 70 years and beyond, and this increase is more appreciable in the white men than in the white women. It is also a little greater in the white men than in the Indian, and about the same as in the Eskimo. The white female and the negro male increase about the same.

The ear breadth increases with age very little and in the negro apparently none at all, but not enough negro ears were measured to establish this. The increase is greatest in the white men. 
The physiognomic index decreases with age except in the Eskimo female, the white female decreases less than the white male and the Indian male decreases more than any. The decrease in the index is due to the greater increase in length than breadth of the ear with increasing age.

\section{CHANGES IN THE EAR DURING GROWTH}

Fetal stage: The ears of 44 negro fetuses and 22 white fetuses were measured and the total fetal length taken. It is seen that there is a decrease in the physiognomic ear index from 75 to 67 in the white ears, with an increase in total fetal length from 30 $\mathrm{cm}$. and less, to $60 \mathrm{~cm}$., but the negro ears are the same in physiognomic index in all the fetal stages, except from 30 to $39 \mathrm{~cm}$. The index of the negroes is greater than that of the whites in fetal life, and thus early the racial characters are evident. This was also determined by inspection of fetal white and negro ears.

The female fetal ear is longer than the male, and the breadth is about the same as the male, which is what was found in the adult.

Stature and ear dimensions, negro children: It is seen that the length of the male negro ear increases from $49.3 \mathrm{~mm}$. when the stature is 90 to $99 \mathrm{~cm}$., to $56.0 \mathrm{~mm}$. when the stature is 140 to $149 \mathrm{~cm}$., and to $59.1 \mathrm{~mm}$. in the adult. Likewise, the female negro ear increases from 51.8 to 54.7 , and to $57.8 \mathrm{~mm}$. in the same periods. The female negro ear is longer than that of the male negro ear until the adult state is reached, after which it is shorter. Likewise, the breadth for the periods mentioned is $33.0,36.0$ and $37.6 \mathrm{~mm}$. for the male negro, and $32.5,34.3$ and 36.3 for the female negro. The female negro ear is narrower than the male and this difference is greater in the adult. Likewise, the physiognomic index for the four periods is $67.4,64.0$, and 63.8 $\mathrm{mm}$. for the male negro, and $62.8,62.8$, and 60.8 for the female negro. The index decreases with growth more in the female from the earliest fetal stages up to the adult, and in this way the negro female approaches the white. The decrease in the index continues throughout life. Daffner (6) gives it in white males 
as $73.7 \mathrm{~mm}$. at birth, and 58.7 at 70 years of age; and I found it to be 68.1 in the 22 white fetuses and 55.0 at 60 to 69 years of age in the 'old white' American males, and 69.1 in the 44 negro fetuses and 60.3 at 50 to 59 years in the American negro males.

Stature and ear dimensions, adults: It is seen that the length and breadth of the ear increase with increase of stature, the length relatively more than the breadth, therefore the physiognomic index of the ear decreases with inerease of stature, except among the negroes where the reverse is true. The breadth of the ear increases more than the length with increase of stature in the negro males, therefore the physiognomic index increases with increase of stature. Thus the negro racial characteristics of the ear are emphasized with increase in stature, purity of ear type goes with tallness in the negro males.

If we take the same stature in each group, for instance the stature of 160 to $169 \mathrm{~cm}$., we find that the ear length, breadth and index are not the same in all the groups. Racial differences appear. The Eskimo and Indian ears are the longest, the negro ears are the shortest, the white are in between in length. The Eskimo and Indian ears are the broadest also, and the white and negro ears are equal to each other in breadth. The result is that the index of the Eskimo and Indian ears is low and that of the negro is high, with the white in between.

\section{LITERATURE CITED}

(1) Bean, Robert Bennett 1909 Filipino ears: I. A classification of ear types. Philippine Jour. Science, vol. 4, Sec. A.

II. Ears from Malecon morgue, Ibid, vol. 5, Sec. D. III. Negrito ears, Ibid, vol. 6, Sec. D. IV. Ilongot and Mangyan. Ibid, vol. 6, Sec. D. V. Types among the inland tribes. Ibid, vol. 7, Sec. D.

(2) Bean, Robert Bennett 1912 Morbidity and morphology. A composite study of the incidence of disease and physical form in New Orleans, Louisiana. Johns Hopkins Hospital Bull. vol. 23, no. 262, December.

(3) Bean, Robent Bennett 1914 The stature and the eruption of the permanent teeth of American, German-American and Filipino children: Am. Jour. Anat., vol. 17, vol 1, November.

(4) Brown, Percy 1914 Boston Medical and Surgical Journal, October 15.

(5) Bryant, John 1914 Stasis and human efficiency, Int. Ass. Surg., May.

(6) Daffner, F. 1902 Das Wachstum des Menschen. Anthropologische Studie, Bd. 2, Aufi., Leipzig. 
(7) Fischer, Eugen 1913 Die Rehobother Bastards und das Bastardierungsproblem beim Menschen. Anthropologische und ethnographische Studien am Rehobother Bastardvolk in Deutsch-Südwest Africa. gr. 8, $327 \mathrm{~S}$. Jena.

(8) Godin, P. 1910 Apropos d'asymmetrie auriculaire. Bull. Mem. Soc. Anthrop., Paris, Ser. 6, T. 1, S. 254.

(9) Goldthwait, Joel E., and Brown, Lloyd T. 1910 The cause of gastroptosis and enteroptosis, with their possible importance, as a causative factor in the rheumatoid diseases. Boston Med. and Surg. Jour., vol. 162 , no. 21, pp. 695-702. May 26.

(10) Gudernatsch, J. F. 1914 Feeding experiments on tadpoles. II. A further contribution to the knowledge of organs with internal secretion. Am. Jour. Anat., vol. 15, no. 4, January 15.

(11) Hrdulcka, A. 1900 Anthropological investigations on one thousand white and colored children of both sexes, the inmates of the New York Juvenile Asylum, with additional notes on one hundred colored children of the New York colored orphan asylum.

(12) Karutz, E. 1900 Ein Beitrag zur Anthropologie des Ohres. Arch. Anthrop., Bd. 26, S. 733.

(13) Martin, R. 1914 Lehruch der Anthropologie, pp. 462-474, V. Das aussere Ohr.

(14) Münch, Francis E, 1897 Ueber die Entwicklung des knorpels des Ausseren Ohres, Jena.

(15) SchwalBe, G. 1898 Das äussere Ohr., Handbuch der Anatomie des Menschen Karl v. Bardeleben, Jena, pp. 113-192.

(16) Topinard 1885 Eléménts d'anthropologie générale. 


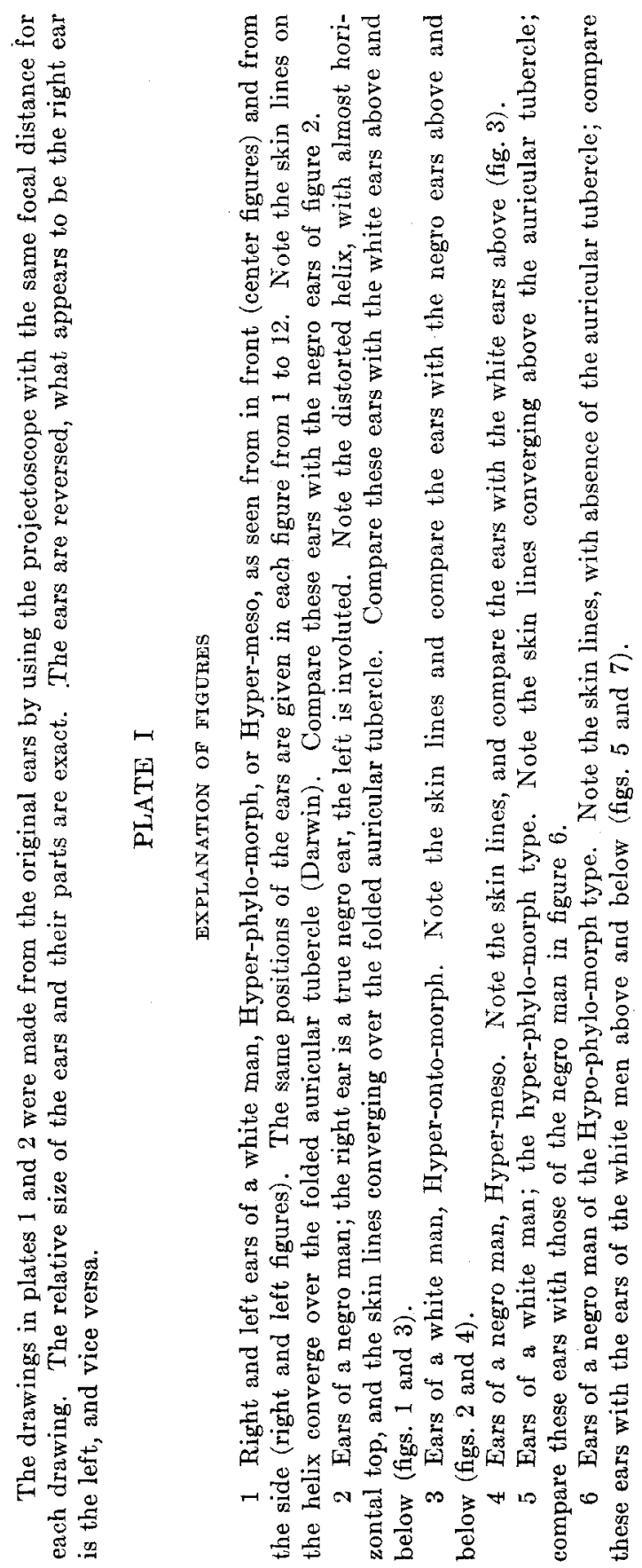


占

(5i)
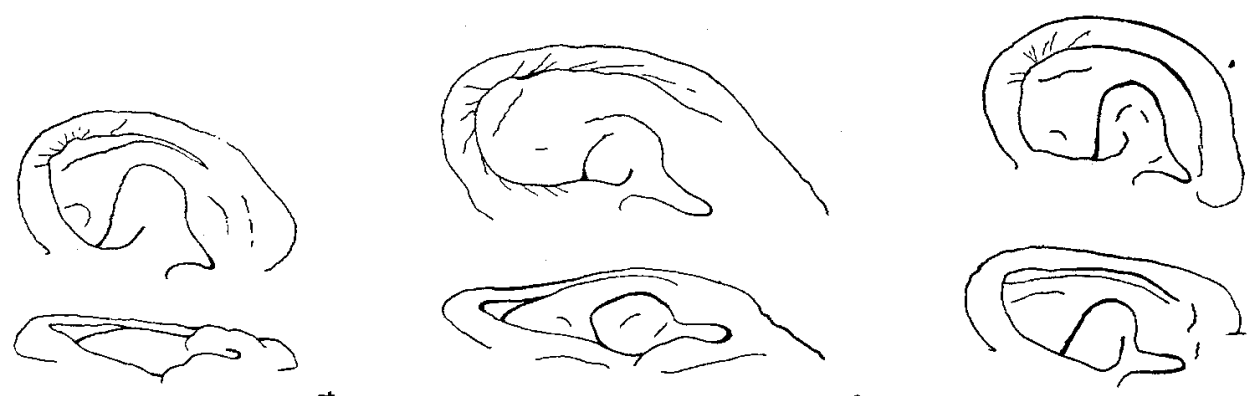

$\longrightarrow$

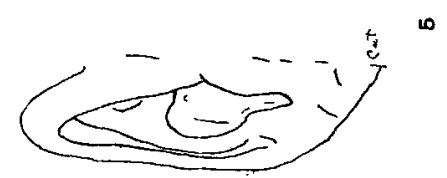

Es:

(Ni,)
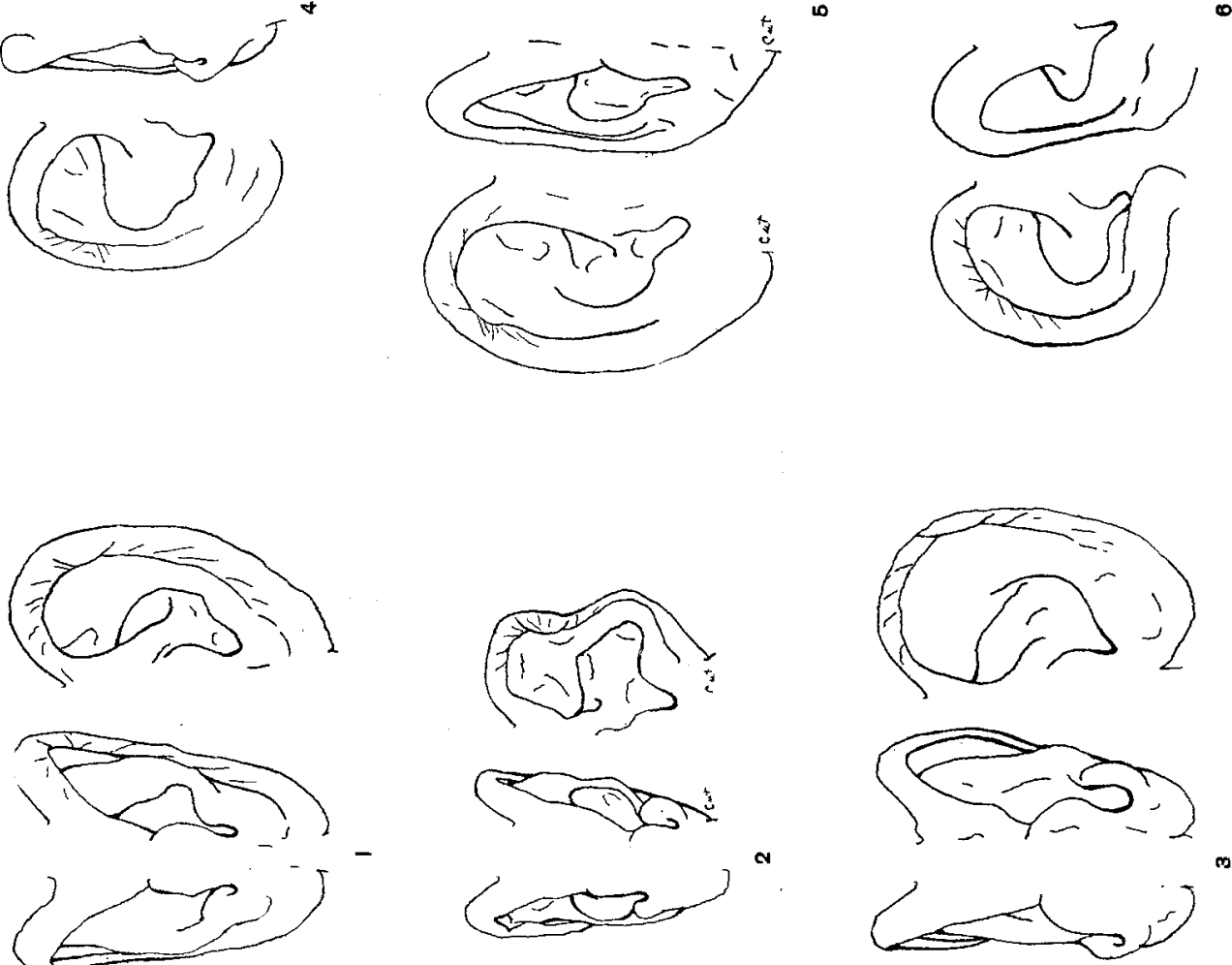

掏
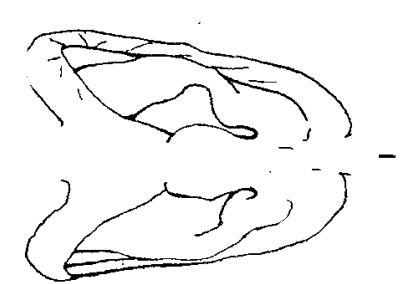

Cose
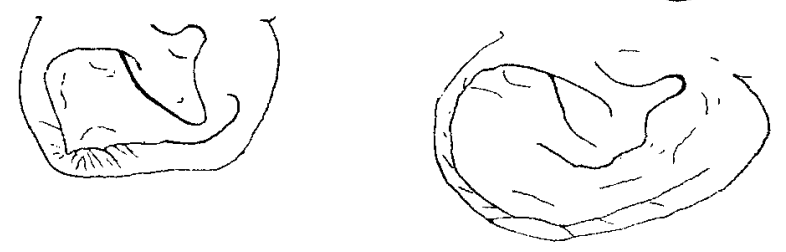


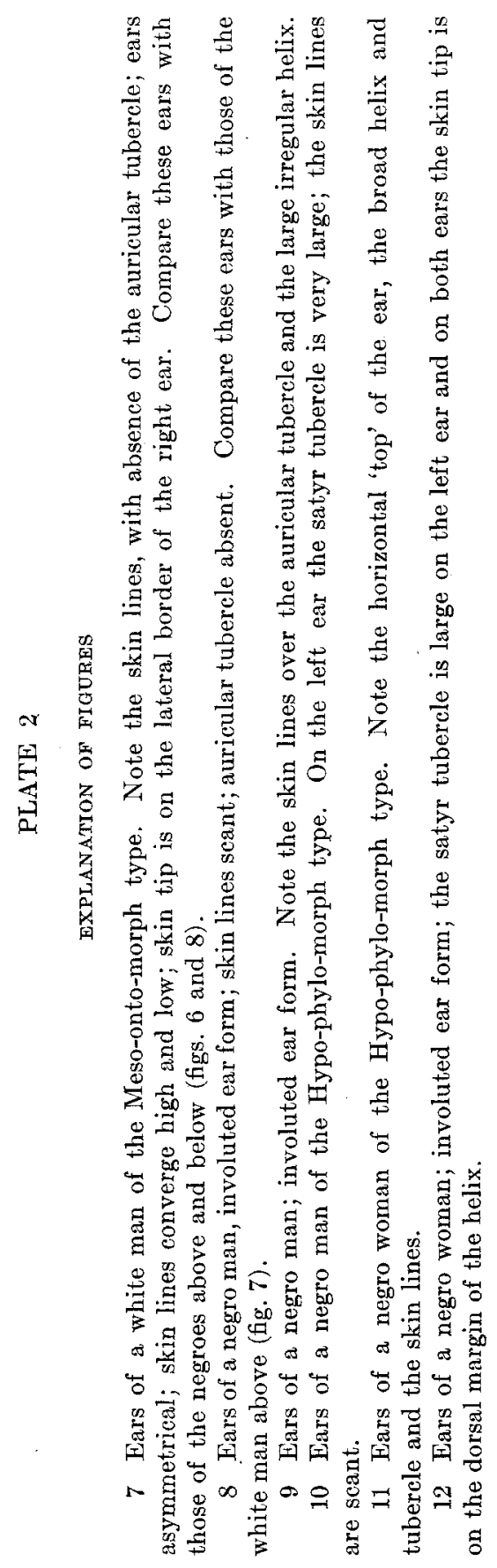


望
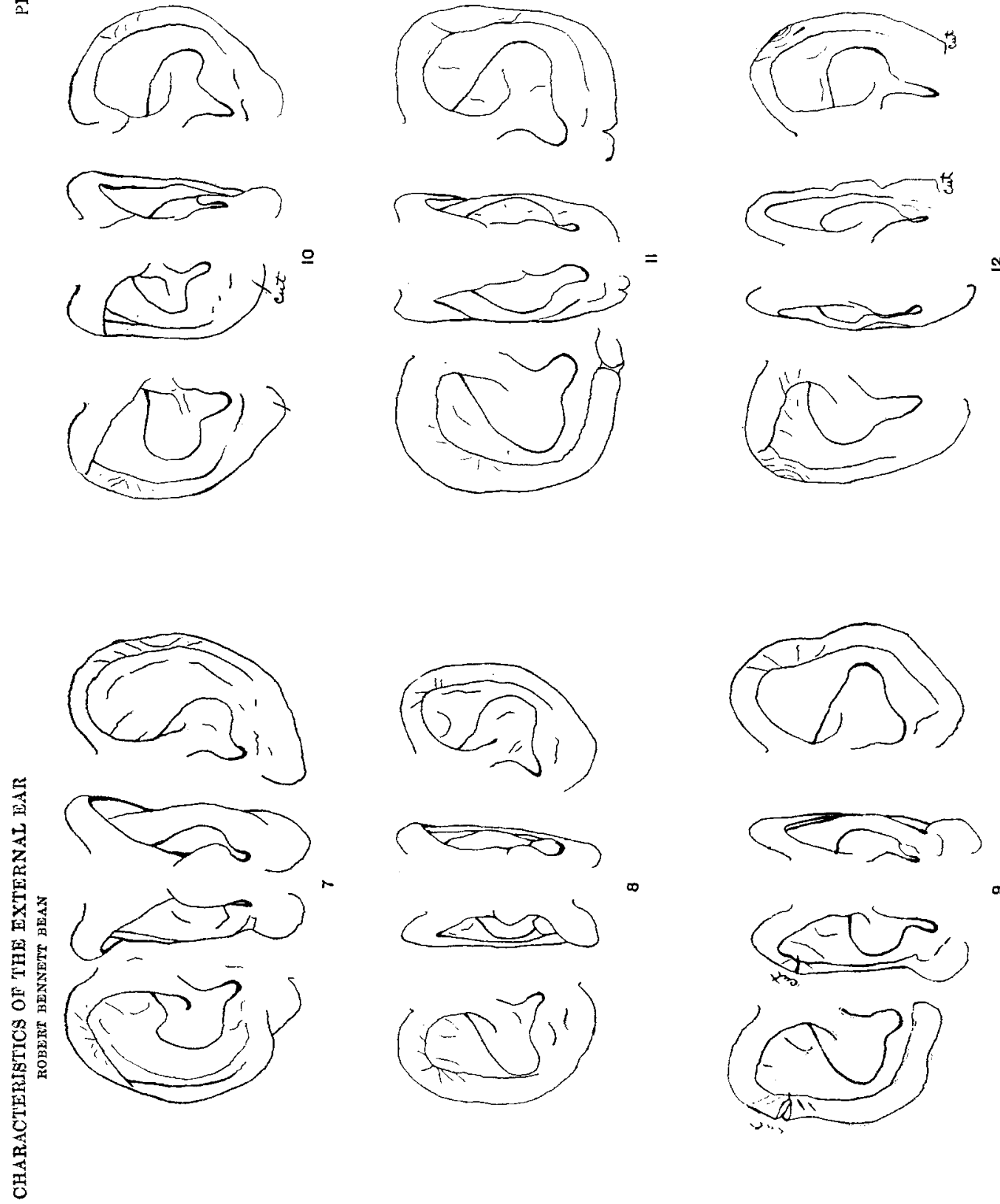


\section{PLATE 3}

\section{EXPLANATION OF FIGURES}

13 Ears of a Filipino woman of the Hyper type; see also figure 16 for the front and back views of the same ear. Note the turning back of the helix, the prominence of the anthelix, tragus and antitragus, which are characteristics of the Hyper type. The skin lines are somewhat irregular.

14 Ears of a Filipino man of the Meso type; see also figure 17 for the front and back views of the same ear. Note the large helix, semi-bowl shape, and sloping shelf lobule, which are characteristics of the Meso type. The skin lines are distinct on the left ear, but indistinct on the right, and converge about the auricular tubercle in each ear.

15 Ears of a Russian of the Hypo type; see also figure 18 for the front and back views of another Hypo ear (Filipino). Note the very large helix, much rolled in, forming a bowl-shaped ear, with shelf lobule, depressed anthelix, tragus and antitragus. These ears are both involuted; the skin lines are obscure.

16 Front and back views of the ear shown in figure 13.

17 Front and back views of the ear shown in figure 14.

18 Front and back views of another Hypo ear (Filipino); see figure 15. 
CIARACTERISTICS OF THE EXTERNAL EAR

ROBERT HENNETT BEAN

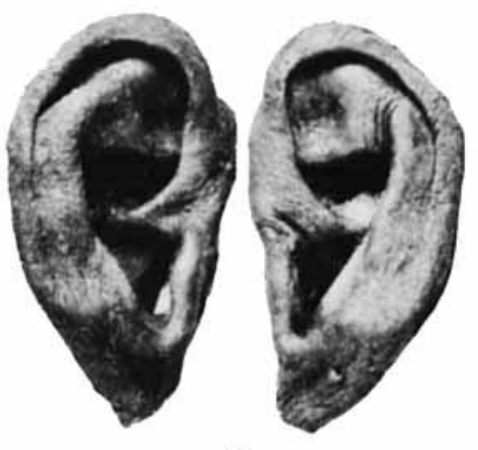

13
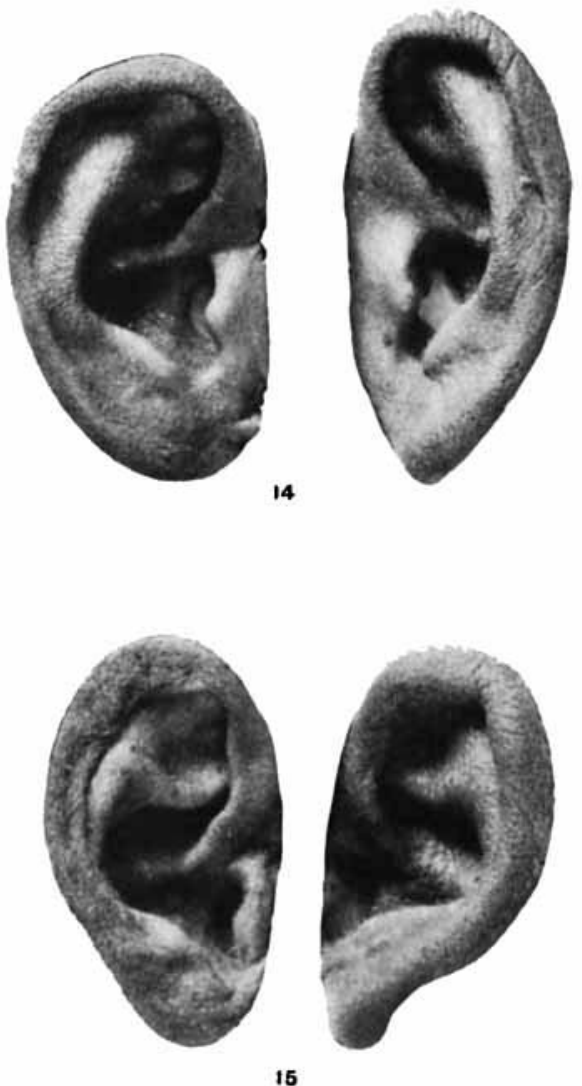

15
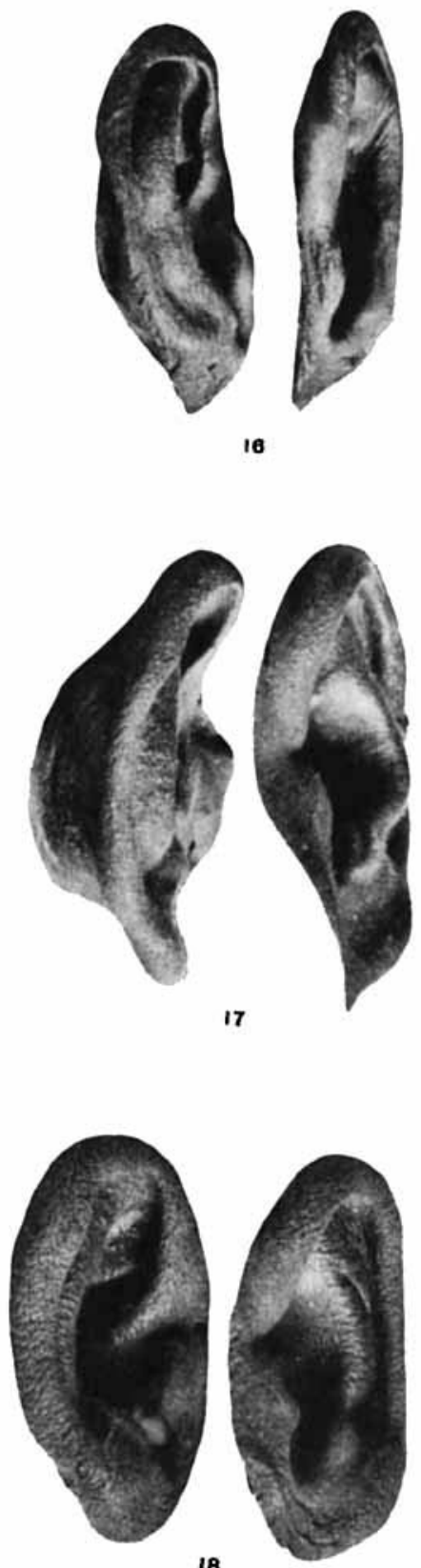

18

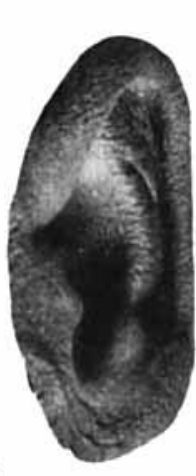

PLATE 3

225

THE AMERCAN JOURNAL OF ANATOMY, VOL. 18 , No. 2

\section{5}

